\title{
Integrating Islamic Values in Teaching English: Lessons Learned from an Integrated Islamic School
}

\author{
Alfian Alfian*, Muhammad Yusuf, \& Uyun Nafiah \\ UIN Sulthan Thaha Saifuddin Jambi, Jambi, Indonesia \\ *alfian@uinjambi.ac.id
}

\section{ARTICLE HISTORY \\ Received : 14 July 2021 \\ Revised : 9 November 2021 \\ Accepted : 11 December 2021}

\section{KEYWORDS}

Integrated Islamic School

Islamic Values

Teaching English

Teaching Practice

Teaching Materials

Lesson Plans

\begin{abstract}
Learning English is very closely related to learning western culture, which might contrast with Islamic values, the dominant religion in Indonesia. This study finds merit in finding out the implementation of Islamic values in teaching English at an Integrated Islamic school in Indonesia, where the school chosen curriculum mandated that the subject be integrated with Islamic values since all the students are Muslim. This case study took place at an Integrated Islamic School, and the data were collected through interviewing seven English teachers and conducting a thematic analysis on their lesson plans. All the teachers admitted that integrating Islamic values in the English lesson was essential. Still, the thematic analysis showed that their perceptions about the importance of integrating Islamic values in English learning were not firmly in line with the implementation in the teaching and learning process. The teachers' lesson plans (In Indonesian: Rencana Pelaksanaan Pembelajaran/RPP) did not depict substantial integration of Islamic values. This study recommends the practical ways of integrating Islamic that could improve teachers' understanding of Islamic values in English learning, additionally pointing out a need to develop the curriculum and teaching materials that incorporate Islamic values. This study offers novel results from the combination of teachers' real practice and RPP analysis.
\end{abstract}

\section{Introduction}

English textbooks or English teaching materials certainly reflect English-speaking countries' habits, identities, and values such as America, Australia, and England. These materials must be introduced to the English language learners because a language can't be taught without involving the cultural elements themselves. According to Brown (1990), "most language symbols cannot be interpreted without knowing the contents of the language culture taught" (p. 130). However, the representation of religious symbols or practice, culture, and beliefs of Western people in the language teaching materials can cause conflicts and misunderstanding (Rohmah, 2012) for the learners who have different religious beliefs and cultures within the Indonesian context of EFL learning (Amelia, 2012; Rohmah 2012; Rambe \& Salminawati, 2019; Wijayanto, 2020) whose learners are predominantly Muslim.

Research has constantly shown that the cultural practice and beliefs of western people demonstrated in the teaching material such as books and authentic material such as from social media influence the students' way of life and thinking (Cahyo et al., 2019; Hasyim \& Suhono, 2017; Rohmah, 2012; Wijayanto, 2020;). Students are eager to practice what they have learned and seen from their learning in and outside the classroom. What they have practised could be new culture for them, and some do not think it contradicts their belief. For example, the concept that God does not exist held by certain Westerners (Atheists) has affected numerous thought groups outside of the West, especially Muslim societies (Wijayanto, 2020). Another example is the widely differing problem of social decorum. As an example, Conversations in English classes frequently include films of men and women interacting daily. The manners of Muslim men and women are strictly regulated in Islamic teachings, such as shaking hands between men and women who are not mahromes (a mahrome is a family member who includes a mother, father, brother, and sister), which is now considered normal even though it is prohibited in terms of religion (Wijayanto, 2020). The values that are suitable to be adopted by the students from western people include discipline, hard work, etc. There may be misconceptions and misunderstandings for the students who have limited knowledge about their different culture and religion.

To avoid students' misconceptions about cultural differences and religious beliefs in English teaching materials as well as to improve their understanding about the similar side of western culture with the Islamic values, a teacher is strongly encouraged to explain clearly to the students about the differences and similarities (Wijayanto (2020). The integration of Islamic values can be one way of better understanding cultural and belief differences (Isa, 2017; Nihayati, 2017; Rohmah, 2012; Umam, 2014). 
Integrating Islamic values can be done through the lesson when the teachers feel that the teaching material would raise cultural differences. This includes classroom activities (Madkur \& Albantani, 2018). The current curriculum has recommended that the integration of character, which is similar to Islamic values, begin from designing the lesson plan, which is stated in K-13 (Curriculum K 13) focusing on KI (Kompetensi inti/core competency) 1 (spiritual competency) and KI 2 (social competency). These competencies aim to build strong engagement with religious aspects and moral values on students' learning process and outcomes.

Studies on integrating Islamic values in English subjects have been conducted; however, most of the studies is focused on library research and on ways of incorporating Islamic values conceptually (Madkur \& Albantani, 2018; Amelia 2012; Hasyim, \& Suhono, 2017; Irwan, 2020; Rohmah, 2012; Umam, 2014). Although current empirical studies focusing on teachers' beliefs and challenges in integrating Islamic values (Farah et al., 2021; Hassim \& Aziz, 2021; Hidayati, 2016; Rohmah et al., 2019; Wijayanto, 2020) has been done yet, there was relatively little evidence reported on the teachers' actual practices and knowledge on integrating Islamic values, and to the best of our knowledge, there was no a study examining the lesson plan or Rencana Pelaksanaan Pembelajaran (RPP) of the teachers. Thus, the novelty of this study is that this study revealed the integrating Islamic values by exploring the actual practice of the teachers and analysing the RPP used by the teachers. Moreover, this study was conducted at the Integrated Islamic school in which all of the students and teachers are Muslim. Thus, the purpose of this current study is to examine English teachers' practice and knowledge in integrating Islamic values in the learning process and in what ways the teacher incorporates Islamic values into English learning in the class. Besides, this study would be a detailed look at the teacher's lesson plan, whether it has incorporated Islamic values in it or not.

\section{Literature Review}

\subsection{Teaching and Learning English in the Current Context}

English has become one of the compulsory subjects taught from junior high school level to university level in Indonesia since a long time ago. At the high school level, the primary purpose of learning English is to enable learners to use English, either spoken or written. Therefore, the English curriculum was designed to learn the language skills (listening, speaking, reading, and writing) and the language component (grammar, pronunciation, and vocabulary). However, teaching and learning English is not merely made students master the language skills and language components. Still, teaching and learning English should help them develop a good attitude, encourage their enthusiasm, and facilitate motivation toward learning
English (Songbatumis, 2017). Thus, a teacher should also understand what materials should be incorporated and learned in the lesson and how the lesson would be beneficial for them in the future (Derakhshan, 2015). Hence, teaching and learning English aim to achieve both learning goals academically and develop learners' personalities and spirituality for the learners' lives.

To achieve the learning goals and to develop learners' personalities and spirituality of learners in learning English, a lot of factors may contribute, such as teacher, learning materials, teaching methods, learning strategies (Alfian, 2018; 2021), learning environment, and learner`s need (Alfian, 2019). At the curriculum level, the Indonesian government has transformed the curriculum many times. The latest curriculum was called Curriculum K 13. K 13 was to develop student competency, which covered three areas, namely, attitude (spirituality and social), knowledge, and skills (Permendikbud No. 104 Tahun 2014). The knowledge and skills domain is developed through pure teaching and learning English conducted by the teacher based on the syllabus stated on the lesson plan/RPP. The attitude domain covered honesty, discipline, cooperation, tolerance, peace, politeness, initiative, responsibility, social interaction, etc. The developing of these elements of attitude is created through the learning process as the model for the teachers to build student character (Permendikbud No. 104 Tahun 2014)

As stated in the K13 above, to develop the skills and knowledge domain, the teachers teach the students language skills and language components. Teaching language skills and language components requires a proper plan. Thus, teachers' English teachers are needed to design the lesson plan, which covers the plan for teaching and learning activities, including teaching materials, method of teaching, assessment, and incorporates moral characters. The lesson plan also recommends that the teacher state sources of teaching materials, teaching methods, and learning activities. A variety of teaching methods and learning activities are recommended (Aeni et al., 2018; Alfian, 2019), but teaching methods and learning activities are more influenced by the teaching materials used by the teachers. Among the teaching materials, the textbook is dominantly used by the teachers as the source of teaching and learning. The choice of using a textbook as the main source offers a lot of advantages such as promoting good understanding because it built-in structural scaffolding that ensures certain desirable outcomes and leads the learners to the independent learners (Ahmed, 2017). Although the textbook has been designed to develop learners' competency, teaching and learning English in the current context are still full of problems. Research has shown that the problem with teaching and learning is related to the lack of training in teaching, limited teaching methods, limited knowledge to use IT, and other professional development (Songbatumis, 2017). 


\subsection{Islamic Values}

A growing number of literature on defining Islamic values have been located. Although the definition is ambiguous, an effort to define Islamic values has been made. Syariah (2001) in Elhoshi et al. (2017) stated that religious values refer to the interest of the individual in affairs related to the question: "Who are you?" They are deeply ingrained beliefs, priorities, and underlying assumptions that shape your attitudes and behaviours (Elhoshi et al., 2017). Thus, Islamic values are what is taught by the Islamic religion that affects how someone behaves in their life. Thus, the things that are the foundation of Islamic values, the values that Allah SWT reveals in the Qur'an, and the practice of the Prophet Muhammad peace be upon Him (Yusouf et al., 2015: 97). It could also be interpreted as all forms of goodness in Islam (Nihayati, 2017). Islamic values are also indicated in good character.

Lubis et al. (2021) argue that the aspects of Islamic values are divided into three types, namely the values of faith (Aqidah), the values of worship (ibadah), and moral values (Akhlak). The first Islamic value is the values of faith (Aqidah) teach humans to believe in the existence of God Almighty, and God Almighty is the only creator of the universe, which will always supervise and calculate all human actions in the world. In the Muslim teaching, aqidah is crucially important because the first lesson about Islam that a moeslem should understand is the Syahadah which admits that the only God is Allah SWT. For Muslims, this means that they must only worship Allah SWT. Thus, to show that they have good Aqidah, which believes that Allah SWT is the only God, a moeslem should follow to acknowledge the Holy Prophet of Muhammad (SAW) as the ideal model to emulate in submission to Allah. Thus, every word and action of the Prophet should be followed in daily living (Embong, Safar, \& Basiron (2020). Embong et al. (2020) also stated that when students demonstrate complete trust in Allah and implement concepts leading to good deeds daily, aqidah teaching is considered successful. Sholihah, Aminullah, \& Fadlillah (2019) argue that implementing Aqidah values to students can be done through asking the student for discussing essential aspects in the aqidah, for example, teaching Islamic law, teaching reading Alqur'an, the right of parents, and teaching Islamic characters.

The second Islamic value is the ibadah (the values of worshipping) or Islamic rituals (Hidayat, 2017). Etymologically, ibadah/worshipping means humble and submissive. According to Hidayat (2017), the primary Islamic rituals are the Five Pillars of Islam (shahada, salat, zakat, sawm, and hajj), a framework for the religious act of worship or ibadat and a sign of commitment to the faith. Hidayat (2017) also emphasises that Muslim individuals who regularly exercise these ibadat in their daily lives will be considered more pious Muslims and thus strengthen their Muslim identity. A Muslim should do these rituals based on the sincerity of heart to achieve the pleasure of Allah. Experiencing ibadah values will bear the wise and honest human (Lubis et al. (2021) because principally doing Ibadaha teach us to do good deed (Rohmah \& Masruroh, 2019). Beside the basic foundation of Islam, there are two kinds of ibadah namely, special ibadah or ibadah mahdhoh and general ibadah or ibadah ghoir mahdhoh (Mahfud, Mahmudah, \& Wihartati, 2017). Hidayat (2017) also argues that the Muslim identity can be constructed through practising the Islamic ritual that teaches that traditions to every Muslim. Among the ibadah values are teaching Alqur`an, teaching prayer, fasting, paying zakat, and teaching hajj (Suryana, 2007; Wibowo, 2019).

The third Islamic value is moral values (Akhlak). Akhlak is derived from khalaqa - khuluqun, which means attitude or laterally translated into English as "ethics" (Elhoshi et al., 2017), which constantly teaches humans to behave well to the right and good norms or manners. In Islam, ethics relates to the religion, including its precepts, directives, etiquettes, and human interactions. The ethical philosophy developed by the teachings of the Qur'an and articulated by the Prophet Muhammad (PBUH) through conduct and speech is known as Islamic ethics. Akhlak can also be seen as the adab/Islamic manner (Elhoshi, , Embong, Bioumy, , Abdullah, \& Nawi, 2017). According to Lubis, Syaukani, Harahap, \& Siregar (2021), Ahklak Values are significant for the students and must be infused by a Muslim as a good character as a true moeslem. Among the example of good akhlak is teaching/ spreading knowledge to others, helping others, caring, being honest, and like to give charity (Rohmah, M., \& Masruroh, L. (2019). Practising the concept of akhlak values is seen from people just, disciplined, honest, responsible, and like to help others. These moral values would lead to a peaceful, harmonious, and balanced human life.

Although Lubis et al. (2021) divided the Islamic values into three kinds, the Islamic values cover a lot of sides of human life. as was explained at the beginning. Islamic values are the values covered in the Qur'an and Hadith that are the source of Islamic values, which include the ideal ways of life as a human being, such as helping other, honest, responsibility, courage, etc. in the curriculum k 13, the Islamic values have stated the form of character and based on the core competency as stated in the Permendikbud No. 69 Tahun 2013 tentang Kerangka Dasar (KD) dan Struktur Kurikulum (KI). In the core competency that the student should Live and practice the teachings of the religion, he adheres to, Appreciates and practices honest behaviour, discipline, responsibility, caring (cooperation, cooperation, tolerance, peace), polite, responds, and be proactive. 
The division by Lubis et al. (2021) is one of the examples of Islamic values that the teachers and the student should acknowledge. Thus, it is clear that the values of Islamic teachings will bring people to happiness, welfare, and human safety both in life in the world and in the hereafter (Nihayati, 2017). Since Islamic values cover everything in human life, the teachers need to identify and sort out the Islamic values that could be integrated into the process and teaching material EFL, which would make it easier for teachers to implement it.

\subsection{Integrating Islamic Values in Teaching EFL}

Integrated learning is learning that connects learning to build up the unity of knowledge. Integrated learning can also be interpreted as a learning model by combining several subjects/materials/themes based on specific topics that are integrated to explore students' knowledge based on interactions with the environment or experience to provide meaningful experiences for students (Nasekum, 2015). Fogarty (1991) divides the integrated learning model into 10 (ten) models. One of which is the Connected Model; the Connected Model is based on the assumption that a subject can be shaded to a particular subject. The connected model tends to be used by teachers for integrating Islamic values into English subjects. In the connected model, English learning can be overshadowed by Islamic values. As one example of integrated learning is raised by Rohmah (2012), she suggested that the values are integrated into learning English in three ways: First, by compiling or using EFL books following Islamic messages. Second, by using authentic material that contains Islamic messages, and the third, by using additional material collected by ELTIS. Integrating can be done by stating Islamic values in the lesson plans, learning materials, instructional media, the behaviour of teachers, opening and closing the lesson (Isa, 2017). Furthermore, the teacher should also enrich the lesson by integrating Islamic values in the subjects they are teaching (Hasan, 2012).

There are a lot of ways of integrating a lesson into another lesson. According to Liddicoat et al. (2003), there are five ways of integrating a lesson into another lesson. First, active construction, comprehension of plainly expressed cultural characteristics in the text, music, and drama: Second, establishing a link between local culture and foreign civilisations, as well as Islamic culture; Third, social engagement, which includes group work or working in pairs to debate a certain issue and expressing one's opinion to others. Fourth, students can be responsible and uphold Islamic principles while respecting other cultures by reflecting on what is happening or commenting on others' opinions; responsibility, leading the teaching and learning process.

The importance of incorporating Islamic values into each subject as a manifestation of the goal of national education and improving moral education has triggered the researcher to conduct studies related to the integration of Islamic values into English lessons (Ali, 2018; Amelia, 2012; Madkur \& Albantani, 2018; Rohmah, 2012; Umam, 2014). For example, Rohmah (2012) stated that Islamic values could be integrated into English subjects in three ways: compiling Islamic-based English books, using authentic material, and using books compiled by ELTIS Islamic Life Resource Pack. Umam (2014) also conducted a similar study, who recommended that authentic material about Islam can be used in learning English.

In addition, Khamdan (2009) conducted a case study by interviewing an English teacher in Java. He found that the teacher integrated Islamic values into English lessons by inserting them into a lesson plan, learning materials, and assessment activities. These findings were summarised by Madkur \& Albantani (2018), who argued that the practical ways in integrating Islamic values were through curriculum, learning materials, and instructional activities. Moreover, different ways of presenting values should be described, modelling, and demonstration.

Furthermore, research was conducted by Isa (2017) on the readiness of prospective English teachers in integrating Islamic values in making lesson plans and applying them in learning. A total of 17 English teachers were observed while doing teaching practice. His study showed that English teachers were less able to integrate Islamic values into English learning. There are only six people (35.2\%) who integrate Islamic values into teaching materials, but the teacher cannot relate the teaching material to the verses of the Quran. The study also found that the prospective teachers only integrated the Islamic values at the beginning and end of the lesson by giving greetings and doing prayers.

The studies presented above have a major contribution in integrating Islamic values in learning English. A closer look at the lesson plans of English teachers has not yet been conducted. This study would fill this research gap by conducting a thematic analysis on English teachers' lesson plans and interviewing them to find out how an Islamic school integrates Islamic values in teaching EFL.

\section{Method}

This study explores the integration of Islamic values in teaching and learning English at an integrated Islamic school. Referring to Yin (2018), the design of this study is set as a case study by collecting data through interviews with seven English teachers and document analysis on the teachers' lesson plans (RPP). The profile of seven English teachers is presented in Table 1 below: 
Table 1. Profile of English Teachers

\begin{tabular}{ccc}
\hline No & Teachers' Pseudonyms & Sex \\
\hline 1 & Demiryati & Female \\
2 & Andi & Male \\
3 & Wulandari & Female \\
4 & Sartin & Female \\
5 & Andin & Female \\
6 & Wina & Female \\
7 & Sakima & Female \\
\hline
\end{tabular}

According to the table, six female English teachers and one male teacher are participating in this study. The writer substituted pseudonyms for the interviewee's real names. We chose seven English teachers because we wanted to include all of the English teachers in this school, and there are only seven English teachers at this integrated Islamic school.

Researchers were guided in conducting interviews by research guidelines in questions derived from the central research questions. Before conducting this study, the researcher sought access to the school by sending a permission letter to the school principal, who has the authority to allow the researcher to conduct the study. After obtaining permission, the researcher explained the purpose of the study and asked the willingness of the teachers to participate in the study voluntarily. The teachers were also informed that in reporting the results, the teacher names were pseudonyms, and they may withdraw from the interview at any time as the ethical conduct of the study. After all the agreement, the researcher led the interview by referring to the question sheet to be discussed. The interview was conducted within the school building, and it was audio recorded. After the interview, the teachers voluntarily gave the lesson plan to the researcher to be analysed. Researchers were guided in conducting interviews by research guidelines in the form of questions derived from the central research questions (Creswell, 2008; Creswell, 2013b).

The data from interviews and lesson plan documents were analysed according to the respective theories: Data from interviews were analysed using thematic analysis methods including coding, grouping, and emerging themes (Braun \& Clarke, 2006; Fielding, 2008). The lesson plans were analysed using content analysis (Walliman, 2017; Neuendorf, 2016). The data from the interview were confirmed with the data from the lesson plan. After analysing the data, they are compared and interpreted according to each research question.

\section{Results}

In referring to the purpose of this study which is to find out the integration of Islamic values in teaching and learning English at the Integrated Islamic school in Jambi, the results of interviews and the lesson Plan or Rencana Pelaksanaan Pembelajaran (RPP) analysis demonstrated that all the teachers from this integrated school have similar views that integrating Islamic values in teaching English is important. However, they were not very familiar with the way to integrate Islamic values in the teaching and learning preparation and process. This can be seen from the result of the interview below. Also, the lesson plan they used only describes a general model of a lesson plan in the national curriculum. As a result, their perceptions about the importance of integrating Islamic values in teaching and learning English were not strongly in line with the implementation in the teaching and learning process. However, the teachers in the current research had attempted to integrate Islamic values in their teaching.

\subsection{The Representation of Islamic Values in the Lesson Plan or RPP}

Based on the analysis of the lesson plan (RPP), it was found that the lesson plan was copied from the national curriculum (K13) in which consists of the plan for English teaching and learning activities. RPP consists of nine parts: core competency, Basic competency, Learning goal, Teaching material, Approach and teaching method, learning source and media, Learning Activities, and Assessment. It seems that the RPP does not explicitly incorporate Islamic values in teaching and learning. Ideally, RPP should be designed to integrate Islamic values in every part of the RPP. Therefore, it can guide the teachers in the teaching and learning process by integrating Islamic values. However, Islamic values, such as honesty, courage, responsibility, discipline, etc., have been inserted in the particular section of the RPP. For example, the Islamic values were embedded in the Core competency (KI); Character expected" or character building. The integration has been stated in K-13, focusing on KI 1 (spiritual competency) and KI 2 (social competency). These competencies aim to build strong engagement with religious aspects and moral values on students' learning process and outcomes. Those characters which are part of the Islamic values should be incorporated in the teaching and learning process.

Besides the core competencies, other Islamic values depicted in the lesson plan were activities, such as praying in the opening and the closing of the teaching and learning activities. This Islamic value is written in the Learning activities part. At the opening and the closing of the teaching and learning activities, the class is started with the recitation of a prayer and closes with the prayer and greeting. 
Another part of the RPP that integrates Islamic values is the Assessment part. As it was recommended by the curriculum that there are three areas of the learners that should be assessed: their Attitude (sikap), Knowledge (pengetahuan), and Skill (keterampilan). The teacher observed the students' attitude as parts of Islamic value. Then, the teachers used the assessment sheet, which is similar to the following table.

Table 2. A Look at the Lesson Plan (RPP) Format of Integrated Islamic School of Diniyah Al-Azhar Jambi

\begin{tabular}{|c|c|c|c|c|c|c|c|c|}
\hline \multirow{2}{*}{ No } & \multirow{2}{*}{$\begin{array}{l}\text { Nama Siswal } \\
\text { Student's name }\end{array}$} & \multicolumn{4}{|c|}{ Aspek Perilaku/Attitude } & \multirow{2}{*}{$\begin{array}{c}\text { Jumlah Skor/ } \\
\text { Total Score }\end{array}$} & \multirow{2}{*}{$\begin{array}{c}\text { Skor Sikap/ } \\
\text { Attitude } \\
\text { Score }\end{array}$} & \multirow{2}{*}{$\begin{array}{l}\text { Kode Nilai/ } \\
\text { Grade Code }\end{array}$} \\
\hline & & BS & JJ & TJ & DS & & & \\
\hline 1 & Soedarmo & 75 & 75 & 50 & 75 & 275 & 68,75 & $\mathrm{C}$ \\
\hline 2 & $\ldots$ & $\ldots$ & $\ldots$ & $\ldots$ & $\ldots$ & $\ldots$ & $\ldots$ & $\ldots$ \\
\hline \multicolumn{9}{|c|}{ Description: } \\
\hline BS & \multicolumn{3}{|c|}{ : Bekerja Sama/Cooperation or Teamwork } & $\mathrm{TJ}$ & \multicolumn{3}{|c|}{ : Tanggung Jawab/Responsibility } & \\
\hline $\mathrm{JJ}$ & \multicolumn{3}{|l|}{ : Jujur/Honesty } & DS & \multicolumn{3}{|c|}{ : Disiplin/Discipline } & \\
\hline
\end{tabular}

As it can be seen from the table above, it was written in the assessment document that the teachers assess the students` attitude by looking at their cooperation, honesty, responsibility, and discipline. These all include Islamic values. These aspects of assessing were based on the observation conducted by the teachers on students' attitudes every day. Besides teacher assessment, self-assessment and pair's assessment were also conducted by the students. In addition, the students were encouraged to assess themselves and assess their friends.

\subsection{The implementation of Islamic Values in the English Teaching Process}

As it can be seen that the integration of Islamic values in the RPP was not described thoroughly, as it is only on the core competencies, the opening and closing of teaching, and the last is in the assessment part. However, based on the interviews, the teachers partly integrated Islamic values in the teaching and learning process. The integration was done by opening the lesson, inserting in the teaching material, teaching and learning activities, and closing the lesson.

\subsubsection{Greeting at the Opening of the Lesson}

The result of interviews indicated that the teachers started the lesson by saying "Assalamu'alaikum" (Islamic greeting) and asking the students to recite praying (doa). Therefore, it was in line with the RPP that the teachers started the lesson by asking the student to pray. This was also supported by the result of interviews that teachers asked the student to pray. Andin, an English teacher, stated as follow:

"Every time I want to go to class and will start learning, I always say hello and ask the children to pray before starting English lessons."

Excerpt 1
Andin emphasised that she always says hello when entering class. After saying the greeting, she continued by asking the students to pray before starting the lesson. This has been the inculcation of Islamic values into learning English. After praying, checking the attendance of students as an attitude of discipline.

\subsubsection{Linking learning materials and learning activities}

The implementation of English learning integrated with Islamic values in an integrated Islamic school, is carried out by teachers by internalising it into teaching materials. One example of linking Islamic values in learning is to provide an example with the name in Islam. In giving an example of a character by a teacher, Islamic names are used as suggested by Wina as follows:

"I give names in lessons; I take Islamic names."

Excerpt 2

Providing Islamic names helps students always to remember that they are Muslims. It is even better when someone gives examples of the names of the companions of the Prophet or prominent imams/leaders in Islam. This is also to help students know the characters in Islam so that they admire and follow the morals and struggles of these Islamic leaders.

Besides linking with teaching material, the teachers in integrated Islamic schools are very concerned about their students' learning and teaching activities. For example, students are asked to do zikir (Remembering Allah/Zikrullah), saying Astaghfirullah when students make mistakes as indicated in the conversation with Wina as follow:

"... when a student of mine interferes with a friend or acts evil, then I will tell the child", Come on, kid, Istighfar, you can't be like that "if it's like that, the child will leave".

Excerpt 3 
Istighfar is a means to pray to Allah. This is the real example of Islamic value included in aqidah teaching.

\subsubsection{Closing the lesson}

Based on the interview, some teachers also stated that they asked the students to say hamdallah (Alhamdulillah) after finishing learning activities and closed by the teachers by reciting Assalamu'alaikum as stated by Andi, one of the English teachers:

"I close the lesson by saying Assalamu'alaikum to the students."

\section{Excerpt 4}

The finding of this study indicated that there seems that the teachers do not clearly express the process of integrating Islamic values in their teaching process. The stages of the integration seem to be part of the regular class rituals rather than the specific integration of Islamic values to teaching and learning English.

\section{Discussion}

Referring to the integration of Islamic values in the RPP and teaching and learning process, it was evident that there is very little attention given to Islamic values in the RPP in the teaching and learning process as it was depicted in the finding that Islamic values were described at the Core competencies expected, the opening and the closing of the lesson, and the assessment process. Consequently, the implementation of the integration was done at the particular section of the teaching and learning activities. For example, the lesson was opened and closed by greeting and praying such as "Assalamualaikum and praying. This greeting and praying at the beginning and the closing were part of integrating Islamic values that were found by several researchers (Zaitun \& Wardani, 2018). However, the lecturers did this integration for the sake of formality to the school policy of doing religious activities (Rohmah, Fitriyah, \& Hanifiyah, 2019). These findings are contradicted with the study by Masyhudi, Frasandy, \& Kustati (2020), in which they found that integration of Islamic values should start from the planning stage. It is carried out by incorporating the arguments of the Qur'an and Hadith and Islamic stories in the lesson planning (RPP) and Syllabus.

The result of integrating Islamic values in the learning process indicated that the teachers carried out several ways. For example, the Islamic values were inserted in the opening lesson, linking teaching material and learning activities and closing the lesson. This finding is almost similar to other studies indicating that Islamic values such as prayer and Islamic greeting are incorporated at the lesson's beginning and closing. Although it was not described in the RPP, linking the lesson with Islamic values was done by the teachers. This example of integrating Islamic values was expected. This finding was similar to the study conducted by Ramadanti, (2020), in which her finding stated that students also do zikir because doing zikir is one of the characteristics of Muslims that are always thankful to Allah SWT. However, teachers might remember Allah incidentally because they are not guided in the plan of their teaching, or they are not written in the RPP. In other words, remembering Allah/istighfar was independently applied by the teachers because it is part of their obligation to Allah SWT and the efforts made by the teacher in integrating these Islamic values is to help the students to be aware of religious norms (Transinata, 2018). This should also be stated in the lesson plan/RPP.

Learning material and learning activities are the means to integrate Islamic values. This study found that the teacher gives the Islamic name or the name of the prophet companion in the teaching and learning process. This finding was similar to Amelia's (2012) and Khamdan (2009) study, who incorporated Islamic values by using Islamic names, such as Umar, Abdullah, Zikri, etc. This would help the student recognise the prominent people in the Islamic world, which help students to learn history. Furthermore, Ekowijayanto (2020), in this study, found that the participant like to integrate Islamic values about telling the story of the Prophets.

The findings in this study indicated that the teachers were not very optimal in integrating Islamic values in the English subject. It can be assumed that the teachers have knowledge constraints to implement integrated learning and the knowledge of Islamic values and lack of knowledge about integrated learning and lack of knowledge about selfawareness of the integrated learning. Madkur \& Albantani (2017) argued that some English Muslim teachers have limited knowledge of Islam and do not know how to effectively deliver Islamic values in instructional activities. This problem is not unique in value-based education context, as Tiwari (2021) has highlighted the fact that teachers can perform less than ideally despite claims of having successfully performed a certain teaching approach.

Based on the findings, it seems that the teachers have minimal strategies in integrating Islamic values in their teaching and learning. However, several strategies could be used by the teachers in integrating Islamic values or other religious values in their teaching and learning-first, designing a lesson plan that consciously integrates Islamic values. Designing a good RPP is very important because preparing a lesson plan would help the teachers in planning and organising activities as well as managing the time of the lesson (Sahin-Taskin, 2017) since RPP is a document that outlines what will occur during the specific time period (Whitton, Sinclair, Barker, Nanlohy \& Nosworthy, 2004). Thus, the teachers could prepare and organise the values expected to be learned and used in every part of the lesson plan. 
Second, use specific teaching materials and media and technology that incorporate Islamic values. Teaching material is also a very crucial part that can motivate students to learn. An example of teaching material incorporating Islamic values is compiling Islamic-based English books and using books compiled by ELTIS Islamic Life Resource Pack (Rohmah, 2012). Besides teaching materials like the book, the lesson can also be developed by taking advantage of media and technology. For example, a teacher could use online resources, such as websites; youtube channels, live streaming or other online resources that contain religious values.

Third, integrating into learning activities and homework. Many learning activities, such as projects, role play, games, presentations, etc., are the means to integrate Islamic or other religious values. For example, on the lesson topic about "making a phone call," the teachers could direct students to open and close the telephone call by saying "salam or Assalamulaikum" and speaking politely on the phone. In addition, the role-play done by students must use Islamic terms in their conversations, for example, Assalamualikum, Masya Allah, Alhamdulillah (Hasyim \& Suhono, 2017). Concerning student homework,

Second, the stakeholder needs to improve the quality of knowledge and skills of integrated teaching and learning of the teacher. Third, seeking and practising various integrated learning models to motivate and increase students' faith and piety. Fourth, conducting seminars or training to improve teachers' understanding of integrated learning, especially Islamic values in learning English. Fifth, developing curriculum by including integrated learning and teaching material, especially the integration of Islamic values into learning. Finally, this research is a qualitative descriptive study, so further research can be carried out in more depth by using a mixed-method to make the research results more robust.

\section{Conclusion}

Research on the integration of Islamic values into various subjects has been carried out. Previous studies mostly investigated the integration of Islamic values through library research and how to integrate Islamic values conceptually. However, none of the studies covers the integration of Islamic values in the RPP and teaching and learning activities. This study revealed that the integration of Islamic values should be started from designing RPP. This situation makes it easier for the teachers to implement in the teaching and learning activities because an integration model is described in the RPP. In this study, the teachers reported that they have integrated Islamic values in teaching and learning during their teaching and learning activities. The situation, then, raises some possibilities and flexibilities of integration. However, looking at the ways the teacher integrated the Islamic values, it can be concluded that the integration was done because the teacher is a Moslem, and they have to integrate Islamic values.

In principle, the integration of Islamic values in learning has been mandated by the laws contained in the education curriculum. The curriculum has noted the integration of Islamic values contained in the graduates' competencies, which include aspects of Knowledge, Skills, and Attitudes, but who spearheaded the implementation of integration is a teacher who directly emphasized these values with their students. The teachers in the current studies indicated that they have knowledge constraints about Islamic values and integrated learning. If a teacher has been equipped with ways of integrating Islamic values in teaching, then it is likely that learning integration can be done well. However, awareness and knowledge about the material to be integrated into learning can greatly influence the success of learning English itself and the values to be integrated.

This study contributes to the field of integrating religious values in learning to teach and learning English by filling the gap of previous studies which only investigate the integration of Islamic values through library research and on ways of integrating Islamic values conceptually as it is stated that the novelty of this study is that this study revealed the integrating Islamic values by not only exploring the real practice of the teachers but also analysing the RPP used by the teacher. Thus, it could be a model for the teachers in integrating other religious values into teaching and learning. However, this study relies on the data provided by seven English teachers from one integrated Islamic school. It is highly recommended that future studies investigate the integration of Islamic values in more depth by using a mixed-method and involving several integrated Islamic schools.

\section{Acknowledgement}

This research has been completed thanks to the support and funds from the LPPM UIN Sulthan Thaha Saifuddin Jambi. We address our best gratitude to the Rector of Universitas Islam Negeri Sulthan Thaha Saifuddin Jambi for the research grant.

\section{References}

Aeni, N., Jabu, B., Rahman, M. A., Ismail, H., \& Bin-Tahir, S. Z. (2018). The Students' Needs in Maritime English Class at Ami Aipi Makassar, Indonesia. Journal of Language Teaching and Research, 9(6), 1284-1292. http://dx.doi.org/10.17507/jltr.0906.18

Ahmed, S. (2017). Authentic ELT materials in the language classroom: An overview. Journal of applied linguistics and language research, 4(2), 181-202.

Alfian, A. (2018). Proficiency level and language learning strategy choice of Islamic University learners in 
Indonesia. TEFLIN Journal, 29(1), 1-18. http://dx.doi.org/10.15639/teflinjournal.v29i1/1-18

Alfian, A. (2019). Students' Voice: A Need Analysis on Teaching and Learning English at Islamic University. IJET (Indonesian Journal of English Teaching), $\quad 8(2), \quad 63-72$. https://doi.org/10.15642/ijet2.2019.8.2.63-72

Alfian, A. (2021). The favored language learning strategies of Islamic university EFL learners. Studies in English Language and Education, 8(1), 47-64. https://doi.org/10.24815/siele.v8i1.17844

Ali, F. (2018). Incorporating Values of Moderate Islam for the 21 st Century Learners in an English as a Foreign Language Class. Edukasia Islamika, 18-31. https://doi.org/10.28918/jei.v3i1.1676

Amelia, R. (2012), Merancang Pembelajaran Bahasa Inggris Berbasis Pendekatan Islami. Jurnal Pemikiran Islam; 37, http://dx.doi.org/10.24014/an-nida.v37i1.308

Amri, M. N. (2017). Integrasi Nilai-Nilai KeIslaman dalam Pembelajaran Biologi di SMA Islam Al Ulum Terpadu Medan. EDU-RILIGIA: Jurnal Ilmu Pendidikan Islam dan Keagamaan, 1(4). http://dx.doi.org/10.47006/er.v1i4.1067

Arikunto, S. (1998). Prosedur Penelitian Suatu Pendekatan Praktek. Rineka Cipta, Jakarta.

Astrid, A. (2012). Pengintegrasian Pendidikan Karakter dalam Aktivitas Pembelajaran Bahasa Inggris. Ta'dib, Vol. XVII No. 02 Desember 2012 https://doi.org/10.19109/td.v17i02.35

Braun, V. and Clarke, V. (2006) Using thematic analysis in psychology. Qualitative Research in Psychology, 3 (2). pp. $77-101$

Brown, G. (1990). Cultural values: The interpretation of discourse. ELT Journal, 44(1), 11-17. https://doi.org/10.1093/elt/44.1.11

Cahyo, S. D., Umam Muslim, M. R., Rahman, A. N., \& Pratolo, B. W. (2019). Needs Analysis of IslamicBased English Reading Material for the Muhammadiyah Junior High School. International Journal of Evaluation and Research in Education, $8(2)$, 286-292. https://doi.org/10.11591/ijere.v8i2.18647

Cohen, L., Manion, L. \& Morrison, K. (2007). Research methods in education (5th Ed.). London and New York: Routledge Falmer https://doi.org/10.4324/9780203224342

Elhoshi, E. R. F., Embong, R., Bioumy, N., Abdullah, N. A., \& Nawi, M. A. A. (2017). The role of teachers in infusing Islamic values and ethics. International
Journal of Academic Research in Business and Social Sciences, 7(5), 426-436. https://dx.doi.org/10.6007/IJARBSS/v7-i5/2980

Embong, W. H. W., Safar, A. J., \& Basiron, B. (2020). Teaching Aqidah: Islamic Studies in Malaysia. UMRAN-International Journal of Islamic and Civilisational Studies, 7(1), 25-32

Farah, R. R., Waloyo, A. A., \& Sumarsono, P. (2021). Incorporating English and Islamic Knowledge into Workbook Development for Primary School Students. IJOTL-TL: Indonesian Journal of Language Teaching and Linguistics, 6(2), 189-202. https://doi.org/10.30957/ijoltl.v6i2.673

Fielding, J. (2008). Coding and managing data. In G. N (Ed.), Researching social life (3 ed.). London: Sage Publication Ltd.

Fogarty, Robin. (1991). How to Integrate the Curriculum. Palatine, Ilinois: IRI/ Skylight Publishing, Inc.

Fraenkel, J. R. (8). Wallen. NE (2006). How to design and evaluate research in education. 4 the edition.

Fraenkel, J. R., Wallen, N. E. \& Hyun, H. H. (2012). How to design and evaluate research in education (7. ed). New York: McGraw-Hill

Hakim, L. (2012). Internalisasi nilai-nilai agama Islam dalam pembentukan sikap dan perilaku siswa Sekolah Dasar Islam Terpadu Al-Muttaqin Kota Tasikmalaya. Jurnal Pendidikan Agama IslamTa'lim, 10(1), 67-77.

Hasan, N. (2012). Education, young Islamists, and integrated Islamic schools in Indonesia. Studia Islamika, 19(1). http://dx.doi.org/10.15408/sdi.v19i1.370

Hassim, S. H., \& Aziz, A. A. (2021). Using Soleh English (SE) Teaching Materials with The Integration of Cultural and Islamic Values: Islamic Preschool Teachers' Voices. Malaysian Journal of Social Sciences and Humanities (MJSSH), 6(4), 178-190. https://doi.org/10.47405/mjssh.v6i4.733

Hasyim, U. A. A., \& Suhono, S. (2017). Restoring Moslem identity by integrating Islamic values in English speaking class. ATTARBIYAH: Journal of Islamic Culture and Education, 2(1), 1-27. https://doi.org/10.18326/attarbiyah.v2i1.1-27

Hidayat, M. A. (2017). Ibadat, the body, and identity: Islamic rituals and the construction of Muslim identity. The Journal of Society and Media, 1(2), 117. https://doi.org/10.26740/jsm.v1n2.p1-17

Indonesia, P. R. (2003). Undang-Undang Republik Indonesia Nomor 20 Tahun 2003 Tentang Sistem Pendidikan Nasional. Lembaran RI Tahun, (20). 
Indonesia, R. (2014). Permendikbud No. 104 Tahun 2014 tentang Penilaian Hasil Belajar oleh Pendidik pada Pendidikan Dasar dan Pendidikan Menengah. Jakarta: Kemendikbud.

Irawan, Y. (2020). Situating Islamic Values in English Language Teaching: Documenting the Best Practices in Indonesia. Islamika: Jurnal Ilmu-Ilmu Keislaman, 20(01), 95-103. https://doi.org/10.32939/islamika.v20i01.617

Isa, Q.N. M. (2017). pengintegrasian nilai Islami dalam pelaksanaan simulasi pembelajaran bahasa Inggris oleh mahasiswa micro teaching prodi pendidikan bahasa Inggris ftk uin ar-raniry. aricis proceedings, (1).

Khamdan, N. (2009). Integrasi Pengajaran Bahasa Inggris dengan Nilai-nilai Islami di SMP Islam Al-Azhar 15 Cilacap. DISERTASI dan TESIS Program Pascasarjana UM.

Liddicoat, A. J. (2002). Static and Dynamic Views of Culture and Intercultural Language Acquisition. Babel, 36(3), 4-11. https://org/doi/10.3316/ielapa.200204271

Lubis, L., Syaukani, S., Harahap, N. H. Z., \& Siregar, M. F. S. (2021). Muslim Youths and Islamic Values: An Implementation in Tanah Enam Ratus Medan. AtTarbiyat: Jurnal Pendidikan Islam, 4(1). https://doi.org/10.37758/jat.v4i1.247

Madkur, A., \& Albantani, A. (2018). M. Instilling Islamic Values in Foreign Language Teaching: An Indonesian Context. In The International Conference on Education in Muslim Society.(Advances in Social Science, Education and Humanities Research, volume 115, Atlantis Press, 2018) (pp. 97-103).

Masyhudi, F., Frasandy, R. N., \& Kustati, M. (2020). Integrasi nilai-nilai islam dalam pembelajaran bahasa indonesia di Sekolah Dasar Islam Tepadu Azkia Padang. Premiere Educandum: Jurnal Pendidikan Dasar dan Pembelajaran, 10(1), 81-93. http://doi.org/10.25273/pe.v10i1.6243

Nasekun, M. (2014). Integrasi Nilai-nilai Agama Islam dalam Pembelajaran IPS Sejarah di Kelas VIII MTs Ma'arif Wadas Kandangan Temanggung Tahun Pelajaran 2014/2015 (Doctoral dissertation, IAIN Salatiga).

Neuendorf, K. A. (2016). The content analysis guidebook. Sage.

Nihayati, N. (2017). Integrasi Nilai-Nilai Islam Dengan Materi Himpunan (Kajian Terhadap Ayat-Ayat AlQur'an). JURNAL https://doi.org/10.52657/je.v3i1.285
Rahaded, U., \& Widodo, H. (2019). The Constraints of The Teachers in The Implementation of 2013 Curriculum At SMP Negeri 1 Dullah, Maluku. JPP (Jurnal Pendidikan dan Pembelajaran), 25(2), 65-72. http://dx.doi.org/10.17977/um047v25i12018p065

Ramadanti, E. C. (2020). Integrasi Nilai-Nilai Islam Dalam Pembelajaran IPA. Jurnal Tawadhu, 4(1), 10531062 .

Rambe, R. N. K., \& Salminawati, S. (2019). Integration of Islamic Values in English Learning at Madrasah Ibtidaiyah Teacher Training Program (PGMI) UIN North Sumatera. Jurnal Tarbiyah, 26(1). http://dx.doi.org/10.30829/tar.v26i1.410

Rohmah, G. N., Hanifiyah, L., Fitriyah, U., \& Ningsih, A. A. (2019). Islamic Values integration in English Lesson at Madrasah Tsnawiyah: Teachers` Beliefs and practices. Jurnal Bahasa Lingua Scientia, 11(1), 93-106

Rohmah, M., \& Masruroh, L. (2019). Implementasi NilaiNilai Aqidah Akhlaq Dalam Meningkatkan Kepedulian Sosial. Al-Misbah (Jurnal Islamic Studies), 7(2), 39-44. https://doi.org/10.26555/almisbah.v7i2.1149

Rohmah, Z. (2012). Incorporating Islamic messages in the English teaching in the Indonesian context. International J. Soc. Sci. \& Education, 2(2), $157-165$.

Sahin-Taskin, C. (2017). Exploring Pre-Service Teachers' Perceptions of Lesson Planning in Primary Education. Journal of education and practice, 8(12), 57-63.

Seale, C. (2004). Validity, reliability and the quality of research. Researching society and culture, 2, 71-83.

Sholihah, M. A., Aminullah, A., \& Fadlillah, F. (2019). Aksiologi Pendidikan Islam (Penerapan Nilai-Nilai Aqidah Dalam Pembelajaran Anak Di Mi). Auladuna: Jurnal Prodi Pendidikan Guru Madrasah Ibtidaiyah, 1(2), 63-82. https://doi.org/10.36835/au.v1i2.233

Songbatumis, A. M. (2017). Challenges in teaching English faced by English teachers at MTsN Taliwang, Indonesia. Journal of foreign language teaching and learning, 2(2),54-67 https://doi.org/10.18196/ftl.2223

Stake, R. E. (1995). The art of case study research. USA:Sage Publication Inc

Suryana, A. (1996). Toto, dkk. Pendidikan agama Islam untuk Perguruan tinggi, Bandung: CV. Tiga Mutiara. 
Tiwari, T. D. (2021). The Implementation of Communicative Language Teaching Approach in Selected Secondary School: Nepalese Teachers' Perspective . Utamax : Journal of Ultimate Research and Trends in Education,3(3), 187-197. https://doi.org/10.31849/utamax.v3i3.8242

Transinata, T. (2018). Integrasi Pendidikan Cinta Tanah Air dalam Kurikulum Tersembunyi Berbasis Karakter Kebangsaan. PHILANTHROPY: Journal of Psychology. https://doi.org/10.26623/philanthropy.v1i1.679

Umam, C. (2014). Maintaining Islamic values in English language teaching in Indonesian pesantren. Didaktika Religia 2(1), 227-242

Valdes, J. (1990). The inevitability of teaching and learning culture in a foreign language course. In B.Harrison (Ed.), Culture and the Language Classroom (pp. 2030). ELT Documents: 132. London: Modern English Publications.

Walliman, N. (2017). Research Methods: The Basics (2nd ed.). London: Routledge

Whitton, D., Barker, K. L., Nosworthy, M., Humphries, J., \& Sinclair, C. (2016). Learning for teaching: Teaching for learning. South Melbourne: Cengage

Wijayanto, M. E. (2020). The integration of Islamic values in implementation of learning English: Islamic education students perspective. Eternal (English, Teaching, Learning, and Research Journal), 6(1), 18-30. https://doi.org/10.24252/Eternal.V61.2020.A2

Yin, R. K. (2018). Case study research and applications: Design and methods (6th ed.). Sage Publications.

Yusof, M. A. M., Shamsudin S., \& Raof, A. H. A. (2008). Integrating Islamic Themes and Values in English Classes. Motivation to Learn English: Is it Determined by Gender, proficiency levels, and Plans after Graduation?

Zaitun, Z., \& Wardani, S. K. (2019). Islamic values in the context of English learning and teaching. English Language in Focus (ELIF), 1(1), 70-80. https://doi.org/10.24853/elif.1.1.70-80 